\title{
Effectiveness of Granular and Liquid Insecticides against Chilo partellus on Maize in Pakistan
}

\author{
Zahid Khan ${ }^{1-3}$, Qurat ul Ain ${ }^{2,3}$, Abdur Raqib ${ }^{3}$, Mian Sayed Khan ${ }^{2,4}$, Lianxi Xing1* \\ ${ }^{1}$ College of Life Sciences, Northwest University, Xi'an, Shaanxi Province, P. R. China \\ ${ }^{2}$ Department of Zoology, Hazara University, Dodhial, Mansehra Khyber Pakhtunkhawa, Pakistan \\ ${ }^{3}$ Agriculture Research Station, Baffa, Mansehra, Khyber Pakhtunkhawa, Pakistan \\ ${ }^{4}$ Dean of Sciences, University of Swabi, Anbar, Khyber Pakhtunkhawa, Pakistan
}

Received: 23 October 2018

Accepted: 3 January 2019

\begin{abstract}
Considering the economic importance of the maize Zea mays (Poales: Poaceae) crop and the losses caused by the maize stem borer, an experiment was carried out in a plot of $15 \mathrm{~m}^{2}$ that was equally divided into three replications using randomized complete block design to find the effect of granular and liquid insecticides on Chilo partellus and crop yield. The trial was laid out at the Agricultural Research Station in Baffa, Mansehra, Pakistan during the Kharif season 2015. In this experiment, granular insecticide Carbofuran 3G and liquid insecticides Cypermethrin10 EC, Endosulfan 35 EC, Karate 2.5 EC and Chlorpyrifos $10 \mathrm{EC}$ were used for treating maize stem borer. The obtained results revealed that Carbofuran $3 \mathrm{G}$ proved significantly to be the most effective in reducing plant damage, the number of dead heart plants and the number of pest larvae. Additionally, the treatments caused an increase in grain yield. The liquid insecticides Cypermethrin and Karate ranked second, and Endosulfan and Chlorpyrifos ranked third in efficacy against the pest. On the basis of present findings, it was recommended that the granular form of insecticides in general and Carbofuran 3G in particular may be used for effective control of $C$. partellus in maize crop. The granules should be applied in plant whorls, which will give better results than application through other methods. In the case of foliar applications, Cypermethrin is recommended to get effective control among other liquid formulations. Although the chemical treatments which were used in this research gave good control of C. partellus infestations and increase in yield as compared to check, some variations still occur in the amount of damage, population density of the pest and yield of crop. These differences may be due to differences in types of treatments, methods of experimentation, and environmental factors like temperature, humidity etc.
\end{abstract}

Keywords: Chilo partellus, granular and liquid insecticides efficiency analysis, plant leaf and stem damage, crop yield

*e-mail: 1xxing@nwu.edu.cn 


\section{Introduction}

Maize crop ranks third after rice and wheat in Pakistan, and second in Khyber Pakhtunkhwa [1-2]. In Pakistan, $4.8 \%$ of the total cropped area consists of maize, which is grown on 0.939 million hectares with total annual grain production of 3.34 million tons, which made an average grain yield of 3.56 tons per ha [3-6]. Maize crop has high yield capacity but it is affected by nematodes, weeds, insect pests, birds and diseases [7-9]. Important insect pests are weevils, beetles, grain borers, root worms and virus vectors such as leafhoppers and aphids [10-12]. Chilo partellus damaged the crop up to $75 \%$ [13-15]. Damage or larval feeding to the developing point of maize plants results in "dead hearts", which is significant during the first 2-3 weeks after seedlings emerge [16-17]. This type of feeding is described by pin holes and window panes [18-19]. Maize stem borer grows constantly throughout the year when host plants exist and temperature is favorable for their development.

Prevented infestation of $C$. partellus by chemical insecticides, mostly granular formulations at whorl or soil application [20-22] and as well as some liquid form of insecticides, is also recommended in order to avoid the target pests [23-24]. The crop fails completely due to severe infestation at seedling, vegetative growing, flowering and post-harvest stage [25-26]. Present studies were planned in order to achieve the following objectives:

- Find the comparative effects of granular and liquid insecticides against Chilo partellus.

- Determine the efficacy of the tested chemicals on crop yield.

\section{Materials and Methods}

\section{Study Area}

The geographical location and position of the study area was Mansehra District of Khyber Pakhtunkhwa, which consists of three tehsils, namely Mansehra, Balakot and Oghi. The district is located from $72^{\circ}-49^{\prime}$ to $74^{\circ}-08^{\prime}$ east longitudes and $34^{\circ}-14^{\prime}$ to $35^{\circ}-11^{\prime}$ north latitudes. The entire area of this region is 4579 square kilometers. Mansehra makes its border in the east to Muzaffarabad District, in the north to Battagram District, in the west to Buner District and in the south to Abbottabad District [27].

To find the comparative effects of granular and liquid insecticides against $C$. partellus and to determine the efficacy of the tested chemicals on crop yield, an experiment was carried out during the 2015 cropping season at the Agricultural Research Station, Baffa, Mansehra, Pakistan.

\section{Field Preparation}

Local maize variety BS1 was sown in a randomized complete block design (RCBD). The size of the experimental trial was $15 \mathrm{~m}^{2}$. It has three replications and each replication was divided into six plots for application of the respective treatments. Each plot was comprised of four rows, and row-to-row distance was kept at $75 \mathrm{~cm}$ and plant-to-plant was $20 \mathrm{~cm}$.

\section{Sowing of Seed}

Sowing was done on June 26, 2015 by putting a single seed in the individual holes. Germination started after 3 days.

\section{Treatments}

On the appearance of infestation, the liquid insecticides that were Cypermethrin, Endosulfan, Karate and Chlorpyrifos were sprayed as per the dosage given in Table 2. However, the granular insecticide (Carbofuran) was applied through leaf whorls after 15 days of germination when the crop was more than 4 leaf stage.

\section{Infestation and Data Collection}

The data recording was started one week after spray and continued at weekly intervals until the harvest of the crop. For this purpose, the central two rows per replicated plot were selected for observation

Table 1. Trade and common names of the pesticides belonging to manufacturer companies.

\begin{tabular}{|c|c|c|c|}
\hline Common name & Trade name & IUPAC name & $\begin{array}{c}\text { Manufacturer } \\
\text { Companies }\end{array}$ \\
\hline Cypermethrin & Arrive & $\begin{array}{r}\text { [cyano-(3-phenoxyphenyl)methyl] 3-(2,2-dichloroethenyl)-2,2- } \\
\text { dimethylcyclopropane-1-carboxylate }\end{array}$ & FMC United \\
\hline Endosulfan & Thiodan & $\begin{array}{r}\text { 6,7,8,9,10,10-Hexachloro-1,5,5a,6,9,9a-hexahydro-6,9-methano- } \\
\text { 2,4,3-benzodioxathiopin-3-oxide }\end{array}$ & Bayer Cop Sciences \\
\hline $\begin{array}{c}\text { Lambda } \\
\text { cyhalothrin }\end{array}$ & Karaty & $\begin{array}{c}\text { [cyano-(3-phenoxyphenyl)methyl](1R,3R)-3-[(Z)-2-chloro-3,3,3- } \\
\text { trifluoroprop-1-enyl]-2,2-dimethylcyclopropane-1-carboxylate }\end{array}$ & Syngenta Pakistan \\
\hline Chlorpyrifos & Lorsban & O,O-Diethyl O-3,5,6-trichloropyridin-2-yl phosphorothioate & Dow AgroSciences \\
\hline Carbofuran & Furadan & 2,3-dihydro-2,2-dimethyl-7-benzofuranyl methylcarbamate & FMC United \\
\hline
\end{tabular}


Table 2. Detail of the treatments applied against Chilo partellus in maize crop.

\begin{tabular}{|c|c|c|c|c|}
\hline S. No & Treatments & Dose/ha & Dose/plot & Methods of application \\
\hline T1 & Cypermethrin $10 \mathrm{EC}$ & $500 \mathrm{ml} / \mathrm{ha}$ & 0.75 lit/plot & Foliar spray \\
\hline T2 & Endosulfan $35 \mathrm{EC}$ & $500 \mathrm{ml} / \mathrm{ha}$ & $0.75 \mathrm{lit} / \mathrm{plot}$ & Foliar spray \\
\hline T3 & Carbofuran $3 \mathrm{G}$ & $20 \mathrm{~kg} / \mathrm{ha}$ & $30 \mathrm{~g} / \mathrm{plot}$ & Whorl \\
\hline $\mathrm{T} 4$ & Karate $2.5 \mathrm{EC}$ & $500 \mathrm{ml} / \mathrm{ha}$ & $0.75 \mathrm{lit} / \mathrm{plot}$ & Foliar spray \\
\hline T5 & Chlorpyrifos $40 \mathrm{EC}$ & $500 \mathrm{ml} / \mathrm{ha}$ & 0.75 lit/plot & Foliar spray \\
\hline T6 & Check (zero treatment) & & & \\
\hline
\end{tabular}

of larvae, dead hearts and plant damage. The record of effectiveness of the treatments was based on infestation levels of the C. partellus. Five plants per plot were inspected at each observation in order to find any infestation symptoms such as holes in the leaves and stem, faeces on the plant parts, the presence of larvae and dead hearts. All the affected plants were tagged for future observation until harvesting of the crop.

\section{Formula for Data Sampling}

The experimental field area of $15 \mathrm{~m}^{2}$ was divided into three replications of equal size. Each one was divided into six plots, on which five different types of chemicals were applied and one was kept free of chemical as check, so for each data sampling of insect pests, five plants were randomly selected in each plot's two central lines and formulated as follows:

$$
\begin{gathered}
\mathrm{r} 1=(\mathrm{p} 1+\mathrm{p} 2+\mathrm{p} 3+\mathrm{p} 4+\mathrm{p} 5) \\
\mathrm{r} 2=(\mathrm{p} 1+\mathrm{p} 2+\mathrm{p} 3+\mathrm{p} 4+\mathrm{p} 5) \\
\mathrm{r} 3=(\mathrm{p} 1+\mathrm{p} 2+\mathrm{p} 3+\mathrm{p} 4+\mathrm{p} 5) \\
\mathrm{r} 1=(\mathrm{p} 1+\mathrm{p} 2+\mathrm{p} 3+\mathrm{p} 4+\mathrm{p} 5) / 5 \\
\mathrm{r} 2=(\mathrm{p} 1+\mathrm{p} 2+\mathrm{p} 3+\mathrm{p} 4+\mathrm{p} 5) / 5 \\
\mathrm{r} 3=(\mathrm{p} 1+\mathrm{p} 2+\mathrm{p} 3+\mathrm{p} 4+\mathrm{p} 5) / 5 \\
\text { Mean }=(\mathrm{r} 1+\mathrm{r} 2+\mathrm{r} 3) / 3
\end{gathered}
$$

\section{Statistical Analysis}

To evaluate yield of the treated and untreated crop, ears from the selected plants were collected, counted and weighed properly. Grain moisture was determined before shelling of the ears. Weight of the grains and cobs were recorded separately after shelling. The recorded data were averaged and compiled in the form of tables. The statistical analyses were performed by using ANOVA of Grap Pad prism 5 to elaborate upon the results.

\section{Results and Discussion}

\section{Infestation of Chilo partellus}

Efficacy of the tested granular and liquid insecticides was determined on the basis of the prevalence of larval infestation on the plant. Three types of observations were performed carefully in order to obtain accurate results with minimum error.

The results in Table 3 indicate that the average number of larvae in the plots treated with Cypermethrin 10 EC were in the range of $0.07\left(1^{\text {st }}\right.$ data $)$ and $0.33\left(6^{\text {th }}\right.$ data) larvae per plant. The populations on the $2^{\text {nd }}, 3^{\text {rd }}$ and $8^{\text {th }}$ observations were equal, i.e., 0.13 larvae per plant. Similarly, the number of larvae per plant on the $4^{\text {th }}, 5^{\text {th }}$ and $9^{\text {th }}$ data was 0.20 followed by 0.27 larvae recorded on the $7^{\text {th }}$ data as compared with check plots.

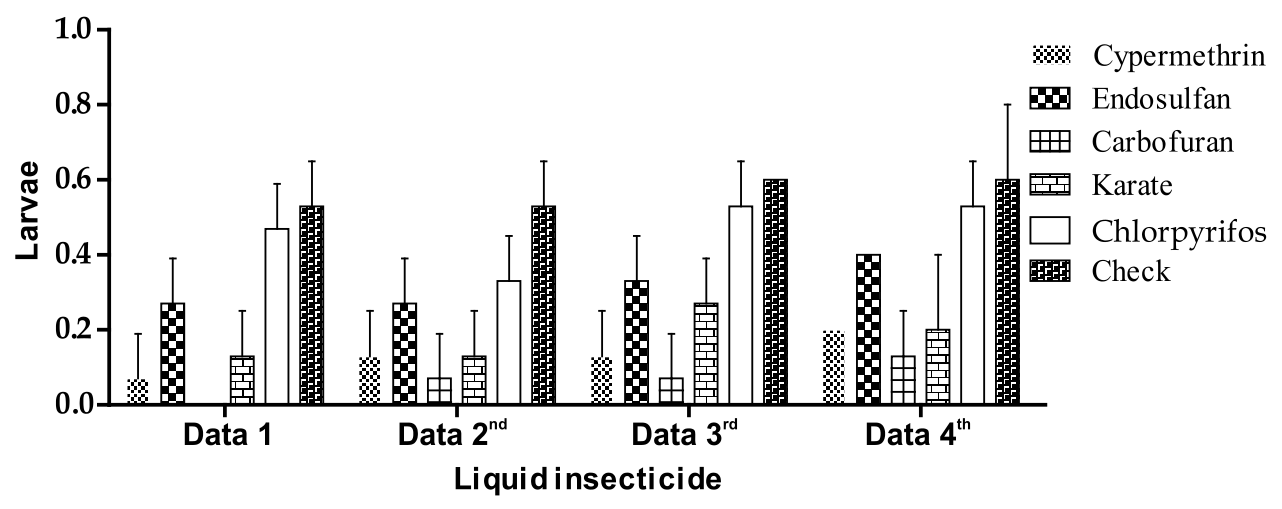

Fig. 1. Control of Chilo partellus with granular and liquid insecticides. 
Table 3. Control of the maize stem borer with granular and liquid insecticides.

\begin{tabular}{|c|c|c|c|c|c|c|c|c|c|c|}
\hline $\mathrm{CT}$ & $1^{\text {st }}$ data & $2^{\text {nd }}$ data & $3^{\text {rd }} d a t a$ & $4^{\text {th }}$ data & $5^{\text {th }}$ data & $6^{\text {th }}$ data & $7^{\text {th }}$ data & $8^{\text {th }}$ data & $9^{\text {th }}$ data & Avg \\
\hline $\mathrm{T}_{1}$ & $0.07 \boldsymbol{a} \pm 0.12$ & $0.13 \boldsymbol{a} \pm 0.12$ & $0.13 \boldsymbol{b} \pm 0.12$ & $0.20 \boldsymbol{a} \pm 0$ & $0.20 \boldsymbol{c} \pm 0.20$ & $0.33 \boldsymbol{c} \pm 0.12$ & $0.27 \boldsymbol{a} \pm 0.12$ & $0.13 \pm 0.12$ & $0.20 \boldsymbol{a} \pm 0.0$ & 0.18 \\
\hline $\mathrm{T}_{2}$ & $0.27 \pm 0.12$ & $0.27 \pm 0.12$ & $0.33 \pm 0.12$ & $0.40 \pm 0$ & $0.33 \boldsymbol{b} \pm 0.12$ & $0.47 \boldsymbol{b} \pm 0.12$ & $0.47 \pm 0.23$ & $0.27 \pm 0.23$ & $0.27 \pm 0.12$ & 0.34 \\
\hline $\mathrm{T}_{3}$ & $0 \boldsymbol{c} \pm 0$ & $0.07 \boldsymbol{b} \pm 0.12$ & $0.07 \boldsymbol{c} \pm 0.12$ & $0.13 \boldsymbol{a} \pm 0.12$ & $0.13 \boldsymbol{c} \pm 0.12$ & $0.20 \boldsymbol{c} \pm 0.0$ & $0.20 \boldsymbol{a} \pm 0.0$ & $0.07 \boldsymbol{a} \pm 0.12$ & $0.13 \boldsymbol{b} \pm 0.12$ & 0.11 \\
\hline $\mathrm{T}_{4}$ & $0.13 \boldsymbol{a} \pm 0.12$ & $0.13 \boldsymbol{a} \pm 0.12$ & $0.27 \boldsymbol{a} \pm 0.12$ & $0.20 \boldsymbol{a} \pm 0.20$ & $0.33 \boldsymbol{b} \pm 0.12$ & $0.33 \boldsymbol{c} \pm 0.12$ & $0.40 \pm 0.0$ & $0.20 \pm 0$ & $0.27 \pm 0.12$ & 0.25 \\
\hline $\mathrm{T}_{5}$ & $0.47 \pm 0.12$ & $0.33 \pm 0.12$ & $0.53 \pm 0.12$ & $0.53 \pm 0.12$ & $0.67 \pm 0.12$ & $0.60 \pm 0.0$ & $0.60 \pm 0.20$ & $0.33 \pm 0.12$ & $0.40 \pm 0.0$ & 0.49 \\
\hline $\mathrm{T}_{6}$ & $0.53 \pm 0.12$ & $0.53 \pm 0.12$ & $0.60 \pm 0.0$ & $0.60 \pm 0.20$ & $0.87 \pm 0.12$ & $0.80 \pm 0.0$ & $0.67 \pm 0.12$ & $0.47 \pm 0.12$ & $0.47 \pm 0.12$ & 0.61 \\
\hline
\end{tabular}

$\boldsymbol{a}(*)$ significant, $\boldsymbol{b}(* *)$ higher significant, $\boldsymbol{c}(* * *)$ highest significant. CT Chemical treatments, $\mathrm{T}_{1}$ Cyp Cypermethrin,

$\mathrm{T}_{2}$ End Endosulfan, $\mathrm{T}_{3}$ Car Carbofuran, $\mathrm{T}_{4}$ Kar Karate, $\mathrm{T}_{5}$ Chl Chloropyrifos, $\mathrm{T}_{6}$ Che Check, Avg Average.

All these individual data were comparable with check plots. Statistical analysis indicated that the effect of the treatment was significantly more than zero treatment at all three levels of significance (significant, more significant and most significant).

Larval population in the Endosulfan 35 EC-treated plots was 0.27 (minimum) per plant in the beginning two and the last two observation dates followed by 0.33 $\left(3^{\text {rd }}\right.$ and $5^{\text {th }}$ data) and $0.40\left(4^{\text {th }}\right.$ data) larvae per plant. The highest number $(0.47)$ was recorded on the $6^{\text {th }}$ and $7^{\text {th }}$ data points. Carbofuran $3 \mathrm{G}$ proved the most effective, giving the lowest number of larvae as compared to the other tested treatments. No infestation was found in the first data while there were only 0.07 larvae per plant in $2^{\text {nd }}, 3^{\text {rd }}$ and $8^{\text {th }}$ data. In $4^{\text {th }}, 5^{\text {th }}$ and $9^{\text {th }}$ data, larval populations were 0.13 per plant. Similarly, the population was slightly increased on the $6^{\text {th }}$ and $7^{\text {th }}$ data points giving 0.20 larvae. It is evident (Table 3 ) that the number of larvae increased in the beginning but showed a decrease after $7^{\text {th }}$ data, as noticed on the $8^{\text {th }}$ and $9^{\text {th }}$ observations. This declining population might have been due to maturation of the crop as fleshy leaves became course and the tiny larvae could hardly feed on these leaves. It was also observed that the decrease in the pest population was at the highest level of significance on the $1^{\text {st }}, 3^{\text {rd }}, 5^{\text {th }}$ and $6^{\text {th }}$ data, followed by higher significance on the $2^{\text {nd }}$ and $9^{\text {th }}$. The decrease in population was at the level of significance on the $4^{\text {th }}, 7^{\text {th }}$ and $8^{\text {th }}$ observations.
The common trend of all the observation dates, as described individually above, was that the treatments significantly decreased the pest infestation as compared to the check plots (zero treatment). The larvae in Karate 2.5 EC sprayed plots were 0.13 comparatively lower than check plots (0.53 larvae/plant) showing significance level in the $1^{\text {st }}$ and $2^{\text {nd }}$ observational data. The highest population was found as 0.40 larvae per plant obtained on the $7^{\text {th }}$ data of observations followed by 0.33 larvae per plant on the $5^{\text {th }}$ and $6^{\text {th }}$ data of observation as compared to 0.87 and 0.80 larvae per plant in the untreated plots, respectively. However, the number of larvae recorded on $6^{\text {th }}$ data presented the highest significant fluctuation with the check, data $1^{\text {st }}$ and $5^{\text {th }}$ presented significant in pest infestation but data $7^{\text {th }}, 8^{\text {th }}$ and $9^{\text {th }}$ presented no significant fluctuation as compared with the check. The insecticide Chlorpyrifos 10 EC was not much more effective as compared to the other chemicals; the larval populations were higher than the other plots. The minimum numbers of larvae were 0.33 per plant on the $2^{\text {nd }}$ and $8^{\text {th }}$ data observations while the maximum was 0.67 on the $5^{\text {th }}$ data, followed by 0.60 on the $6^{\text {th }}$ and $7^{\text {th }}$ data points. In this treatment all the data showed in significant differences with those of check plots. The overall average population of $C$. partellus throughout the experimental duration was found as $0.11,0.18,0.25,0.34$ and 0.49 per plant correspondingly to Carbofuran 3G, Cypermethrin

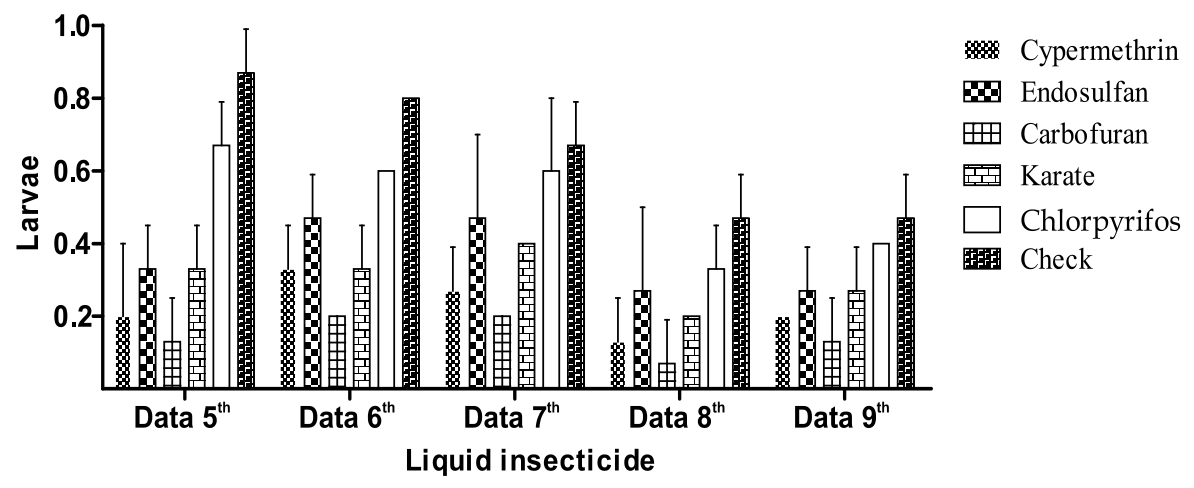

Fig. 2. Control of Chilo partellus with granular and liquid insecticides. 


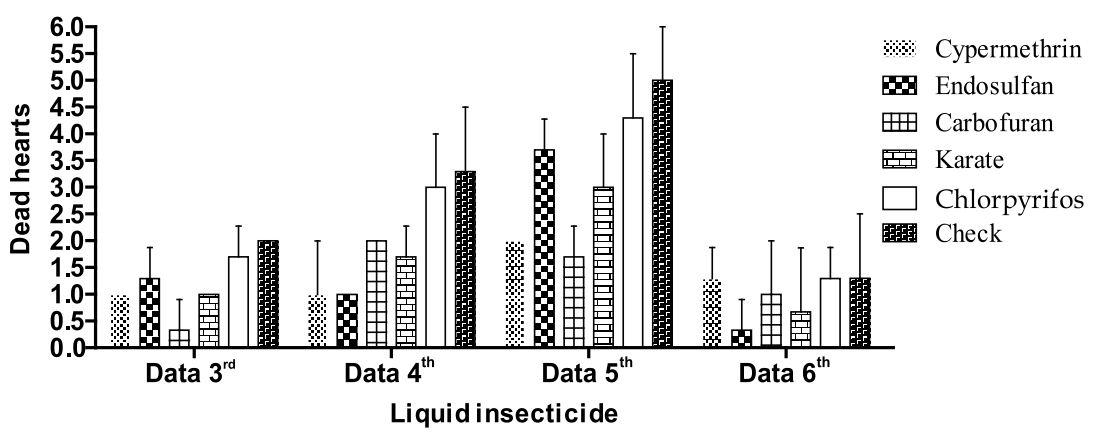

Fig. 3. Incidence of dead heart plants damaged by Chilo partellus.

10 EC, Karate 2.5 EC, Endosulfan 35 EC and Chlorpyrifos $40 \mathrm{EC}$, in ascending order. Seasonal average in the check was 0.61 per plant, which was the highest of the treated plots. As a whole, Carbofuran was proven to be the most effective and Chlorpyrifos the least effective in this experiment.

\section{Occurrence of Dead Heart Plants}

In some cases direct feeding by maize stem borer is not apparently visible. Rather, the affected plants remain dwarfed, showing stunted growth. The appearance of dead hearts is caused due to infestation of the maize stem borer, which was started at early stages of plant growth. It was found that in the beginning two data and the last three data of observation, the dead heart plants were not noticed. The data revealed that the number of dead hearts were being increased up to $5^{\text {th }}$ date of the data record and then declined in the next week followed by zero number. The maximum number was found at the $5^{\text {th }}$ data point in all the treatments (including control). The number of dead hearts in the plots sprayed with Cypermethrin 10 EC was at the level of significance and higher significance on the $4^{\text {th }}$ and $5^{\text {th }}$ data as compared to check plots, respectively, while no significant variations were noted on the other two dates of data record. Similarly, the population recorded in the plots sprayed with Carbofuran 3G showed the level of higher significance on the $3^{\text {rd }}$ and $5^{\text {th }}$ data record but insignificant differences on the other dates in this treatment, too. These statements indicate that all the treatments proved insignificant on the basis of the presence of the dead hearts except $3^{\text {rd }}$ and $5^{\text {th }}$ data in the plots applied with the granular insecticide, the Carbofuran $3 \mathrm{G}$ and $4^{\text {th }}$ and $5^{\text {th }}$ in the plots sprayed with Cypermethrin. It can be inferred from the data in Table 4 that the treatments fairly controlled the targeted pest as showing less number of dead hearts than those found in the check plots.

On the basis of seasonal average (dead heart plants per plot) the efficacy of the tested chemical could be ranked as Carbofuran 3G, Cypermethrin 10 EC, Karate 2.5 EC, Endosulfan $35 \mathrm{EC}$ and Chlorpyrifos 40 EC $(0.55,0.58,0.70,0.70$ and 0.14 when compared with the untreated observations showing 1.28 plants per plot). The insecticide Carbofuran $3 \mathrm{G}$ was the most effective and Chlorpyrifos 40 EC the least effective in this experimental trial. Cypermethrin 10 EC was significantly different at $4^{\text {th }}$ data $(1$ affected plant/plot) and more significantly different at $5^{\text {th }}$ data (2.0 affected plants/plot) than the corresponding infestation found in control plots (3.3 and 5.0 affected plants, respectively).

Table 4. Effect of insecticides on incidence of dead heart plants caused by Chilo partellus; average number of dead heart plants per plot recorded on weekly intervals.

\begin{tabular}{|c|c|c|c|c|c|c|c|c|c|c|}
\hline $\mathrm{CT}$ & $1^{\text {st }}$ data & $2^{\text {nd }}$ data & $3^{\text {rd }}$ data & $4^{\text {th }}$ data & $5^{\text {th }}$ data & $6^{\text {th }}$ data & $7^{\text {th }}$ data & $8^{\text {th }}$ data & $9^{\text {th }}$ data & Avg \\
\hline $\mathrm{T}_{1}$ Cyp & $0 \pm 0$ & $0 \pm 0$ & $1 \pm 0$ & $1 \boldsymbol{a} \pm 1$ & $2 \boldsymbol{b} \pm 0$ & $1.3 \pm 0.58$ & $0 \pm 0$ & $0 \pm 0$ & $0 \pm 0$ & 0.58 \\
\hline $\mathrm{T}_{2}$ End & $0 \pm 0$ & $0 \pm 0$ & $1.3 \pm 0.58$ & $1 \boldsymbol{a} \pm 0$ & $3.7 \pm 0.58$ & $0.33 \pm 0.58$ & $0 \pm 0$ & $0 \pm 0$ & $0 \pm 0$ & 0.70 \\
\hline $\mathrm{T}_{3}$ Car & $0 \pm 0$ & $0 \pm 0$ & $0.33 \boldsymbol{b} \pm 0.58$ & $2 \pm 0$ & $1.7 \boldsymbol{b} \pm 0.58$ & $1 \pm 1$ & $0 \pm 0$ & $0 \pm 0$ & $0 \pm 0$ & 0.55 \\
\hline $\mathrm{T}_{4} \mathrm{Kar}$ & $0 \pm 0$ & $0 \pm 0$ & $1 \pm 0$ & $1.7 \pm 0.58$ & $3 \pm 1$ & $0.67 \pm 1.2$ & $0 \pm 0$ & $0 \pm 0$ & $0 \pm 0$ & 0.70 \\
\hline $\mathrm{T}_{5} \mathrm{Chl}$ & $0 \pm 0$ & $0 \pm 0$ & $1.7 \pm 0.58$ & $3 \pm 1$ & $4.3 \pm 1.2$ & $1.3 \pm 0.58$ & $0 \pm 0$ & $0 \pm 0$ & $0 \pm 0$ & 1.14 \\
\hline $\mathrm{T}_{6} \mathrm{Che}$ & $0 \pm 0$ & $0 \pm 0$ & $2 \pm 0$ & $3.3 \pm 1.2$ & $5 \pm 1$ & $1.3 \pm 1.2$ & $0 \pm 0$ & $0 \pm 0$ & $0 \pm 0$ & 1.28 \\
\hline
\end{tabular}

$\boldsymbol{a}(*)$ significant, $\boldsymbol{b}(* *)$ higher significant. CT Chemical treatments, $\mathrm{T}_{1}$ Cyp Cypermethrin, $\mathrm{T}_{2}$ End Endosulfan, $\mathrm{T}_{3}$ Car Carbofuran, $\mathrm{T}_{4}$ Kar Karate, $\mathrm{T}_{5}$ Chl Chloropyrifos, $\mathrm{T}_{6}$ Che Check, Avg Average. 


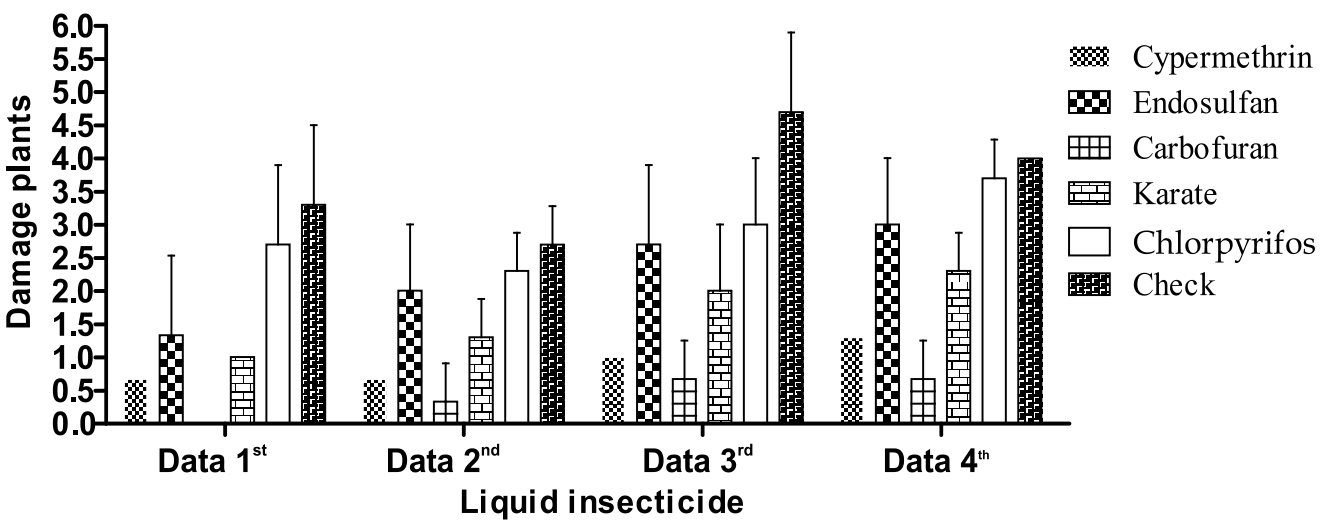

Fig. 4. Damage of maize plants caused by Chilo partellus.

\section{Incidence of Damaged Plants}

Damage to maize plants includes damaged leaves, stems and ears/cobs. It was observed during the data recording that all these parts were damaged by larvae of C. partellus (Table 5). The data showed that the average number of damaged plants in the plots treated with Cypermethrin $10 \mathrm{EC}$ were 0.67 in the $1^{\text {st }}$ and $2^{\text {nd }}$ record of data as compared with the corresponding check plots showing 3.3 and 2.7 plants per plot, respectively. Maximum numbers of damaged plants were obtained as 2.00 plants per plot on the $6^{\text {th }}$ observation and minimum as 0.33 plants recorded on the last observation. Most of the data were significantly better than check plots. Seasonal data was also shown to be significantly effective over untreated crops. The population (1.14) was comparable with that of control (3.67), indicating remarkable variation. This data indicated that damaged plants increased from data $1^{\text {st }}$ to data $6^{\text {th }}$ ascendingly, and then decreased from $7^{\text {th }}$ to $9^{\text {th }}$. It may have been due to the reason that the plants were at growing stage having tender leaves and stems so the attack and feeding of the maize stem borer was easier. In contrast, when it matured, all parts of the plant became hard enough that the insects would not easily feed on it. It can be inferred from the data that the observations recorded on the $1^{\text {st }}, 2^{\text {nd }}, 5^{\text {th }}, 6^{\text {th }}$ and $9^{\text {th }}$ data points revealed significant variation, and data $3^{\text {rd }}, 4^{\text {th }}$ and $8^{\text {th }}$ showed higher significant differences with the check, but data $7^{\text {th }}$ did not show any significance as compared to check.

In the case of Endosulfan, less damaged plants (1.33) were found in data $1^{\text {st }}$ followed by 1.7 in $7^{\text {th }}$ and $9^{\text {th }}, 2$ in $2^{\text {nd }}$ and $8^{\text {th }}, 2.3$ in $5^{\text {th }}, 2.7$ in $3^{\text {rd }}$ and $6^{\text {th }}$ and 3 in $4^{\text {th }}$. The average number of damaged plants of all the data showed insignificant variation with that of check plots corresponding to the respective dates of observation.

In Carbofuran-treated plots, damaged plants were 0 in $1^{\text {st }}$ data followed by 0.33 in $2^{\text {nd }}$ and $9^{\text {th }}, 0.67$ in $3^{\text {rd }}, 4^{\text {th }}$ and $8^{\text {th }}, 1$ in $5^{\text {th }}$ and $7^{\text {th }}$ and 1.3 in $6^{\text {th }}$. Damaged plants in $1^{\text {st }}, 2^{\text {nd }}, 5^{\text {th }}, 7^{\text {th }}$ and $9^{\text {th }}$ described significant alteration with the check. $3^{\text {rd }}, 4^{\text {th }}$ and $6^{\text {th }}$ indicated higher significant differences from those occurring in check plots, while the data recorded on the $8^{\text {th }}$ date of observation was found to be different from that of the check plots at level of the highest significance.

The maximum number of damaged plants (2.7 plants/plot) in the plots sprayed with Karate were noted in $6^{\text {th }}$ data, followed by 2.3 in the $4^{\text {th }}, 2$ in the $3^{\text {rd }}, 5^{\text {th }}$ and $7^{\text {th }}, 1.7$ in the $8^{\text {th }}, 1.3$ in the $2^{\text {nd }}$ and $9^{\text {th }}$, and 1 in data $1^{\text {st }}$ in descending order. All the data in karate treatment indicated that significant difference with the check plot was obtained only during the $8^{\text {th }}$ observation. The other dates of observations were found to be insignificantly different from the respective control observation. Regarding the effect of Chlorpyrifos, the results indicated that this treatment proved to be

Table 5. Damage of maize plants caused by Chilo partellus; average number of damaged plants in treated and untreated plots.

\begin{tabular}{|c|c|c|c|c|c|c|c|c|c|c|}
\hline $\mathrm{CT}$ & $1^{\text {st }}$ data & $2^{\text {nd }}$ data & $3^{\text {rd }}$ data & $4^{\text {th }}$ data & $5^{\text {th }}$ data & $6^{\text {th }}$ data & $7^{\text {th }}$ data & $8^{\text {th }}$ data & $9^{\text {th }}$ data & Avg \\
\hline $\mathrm{T}_{1}$ Cyp & $0.67 \boldsymbol{a} \pm 0.58$ & $0.67 \boldsymbol{a} \pm 0.8$ & $1 \boldsymbol{b} \pm 1$ & $1.3 \boldsymbol{b} \pm 0.58$ & $1.3 \boldsymbol{a} \pm 1.2$ & $2 \boldsymbol{a} \pm 1$ & $1.7 \pm 0.58$ & $1.3 \boldsymbol{b} \pm 0.58$ & $0.33 \boldsymbol{a} \pm 0.8$ & 1.14 \\
\hline $\mathrm{T}_{2}$ End & $1.33 \pm 1.2$ & $2 \pm 1$ & $2.7 \pm 1.2$ & $3 \pm 1$ & $2.3 \pm 0.58$ & $2.7 \pm 1.5$ & $1.7 \pm 0.58$ & $2 \pm 0$ & $1.7 \pm 0.58$ & 2.15 \\
\hline $\mathrm{T}_{3}$ Car & $0.0 \boldsymbol{a} \pm 0.0$ & $0.33 \boldsymbol{a} \pm 0.8$ & $0.67 \boldsymbol{b} \pm 0.8$ & $0.67 \boldsymbol{b} \pm 0.8$ & $1 \boldsymbol{a} \pm 1$ & $1.3 \boldsymbol{b} \pm 0.8$ & $1 \boldsymbol{a} \pm 1$ & $0.67 \pm 0.8$ & $0.33 \boldsymbol{a} \pm 0.8$ & 0.66 \\
\hline $\mathrm{T}_{4} \mathrm{Kar}$ & $1 \pm 0.0$ & $1.3 \pm 0.58$ & $2 \pm 1$ & $2.3 \pm 0.58$ & $2 \pm 0$ & $2.7 \pm 0.58$ & $2 \pm 0$ & $1.7 \boldsymbol{a} \pm 0.58$ & $1.3 \pm 1.5$ & 1.81 \\
\hline $\mathrm{T}_{5} \mathrm{Chl}$ & $2.7 \pm 1.2$ & $2.3 \pm 0.58$ & $3 \pm 1$ & $3.7 \pm 0.58$ & $1.7 \pm 2.1$ & $3.7 \pm 0.58$ & $3 \pm 1$ & $2.7 \pm 0.58$ & $2.3 \pm 0.58$ & 2.7 \\
\hline $\mathrm{T}_{6} \mathrm{Che}$ & $3.3 \pm 1.2$ & $2.7 \pm 0.58$ & $4.7 \pm 1.2$ & $4 \pm 0$ & $4.7 \pm 0.58$ & $4.7 \pm 0.58$ & $3.3 \pm 0.58$ & $3 \pm 0$ & $2.7 \pm 0.58$ & 3.67 \\
\hline
\end{tabular}

$\boldsymbol{a}(*)$ significant, $\boldsymbol{b}(* *)$ higher significant, $\boldsymbol{c}\left({ }^{* * *}\right)$ highest significant. CT Chemical treatments, $\mathrm{T}_{1}$ Cyp Cypermethrin, $\mathrm{T}_{2}$ End Endosulfan, $\mathrm{T}_{3}$ Car Carbofuran, $\mathrm{T}_{4}$ Kar Karate, $\mathrm{T}_{5}$ Chl Chloropyrifos, $\mathrm{T}_{6}$ Che Check, Avg Average. 


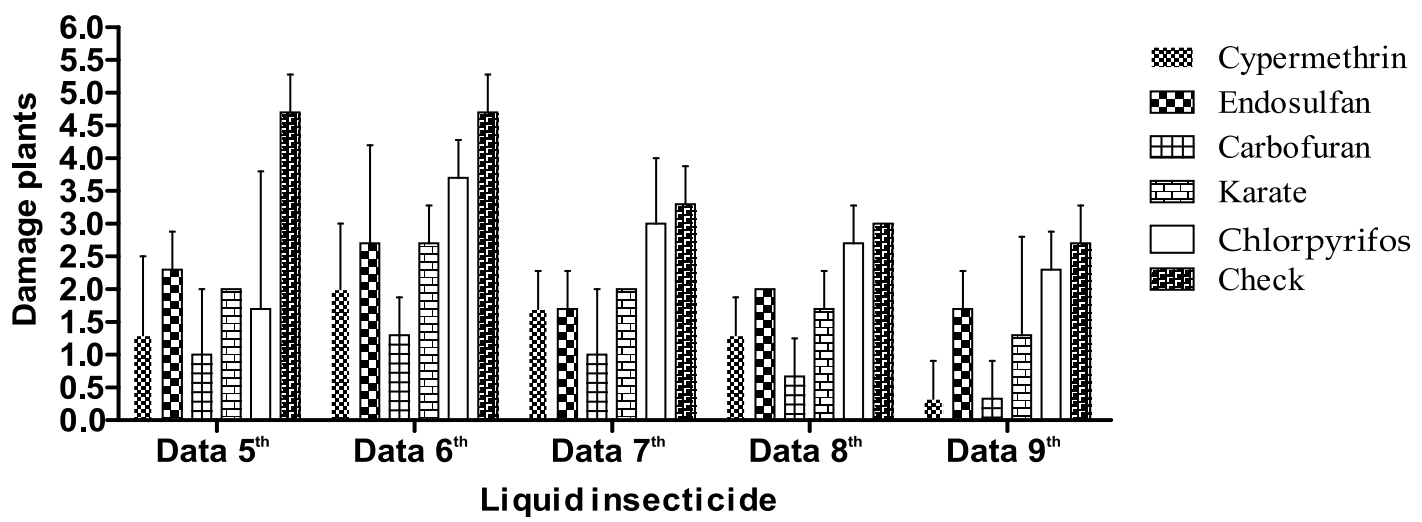

Fig. 5. Damage of maize plants caused by Chilo partellus.

least efficient in controlling the maize stem borer as it gave the highest number of damaged plants (Table 5). Therefore, overall data of this treatment showed no significant reduction in pest population as compared with the other tested chemicals. Maximum numbers of damaged plants were 3.7 found in data $4^{\text {th }}$ and $6^{\text {th }}$, followed by 3 in $3^{\text {rd }}$ and $7^{\text {th }}, 2.7$ in $1^{\text {st }}$ and $8^{\text {th }}, 2.3$ in $2^{\text {nd }}$ and $9^{\text {th }}$ data, but minimum numbers of damaged plants were recorded in $5^{\text {th }}$ data (1.7). Although this treatment was not significantly effective, it gave better results than zero treatment (check). Considering the seasonal data in Table 3, the average number of damaged plants in all treatments (Cypermethrin 10 EC, Endosulfan 35 EC, Carbofuran 3G, Karate 2.5 EC and Chlorpyrifos 40 EC) were obtained as $1.14,2.15,0.66,1.81$ and 2.7, respectively, as compared with the check plots (3.67).

\section{Effects of Treatments on Crop Yield}

Data in Table 6 reveals that maize yield of all the treated plots was higher than that of the untreated plot. In the plots sprayed with Cypermethrin $10 \mathrm{EC}$ and Karate 2.5 EC average number of ears were recorded the same (i.e, $6.7 * \pm 0.58$ per five plants), which showed significant difference with the check plot $(4.7 \pm 0.58)$.
In Endosulfan 35 EC- and Chlorpyrifos 40 EC-treated plots, the average number of ears per five plants were $5.7 \pm 0.58$ and $5.3 \pm 0.58$ respectively, which indicated insignificant variation with check $(5.3 \pm 0.58)$. However, in the Carbofuran 3G-treated plot, the average number of ears $\left(7.3^{* *} \pm 0.58\right)$ was the highest of all treatments and described the highest significant difference with the check. Before shelling weight of ears and after shelling weight of grain and cobs in plots sprayed with Carbofuran $3 \mathrm{G}$ were $2111 * * * \pm 113$ and $2107 * * * \pm 114$ grams per five plants, which was highest of all the treatments, followed by Cypermethrin $\left(1963^{* * *} \pm 126\right.$ and $1960 * * * \pm 126$ grams). These two treatments showed the highest significant difference as compared to check plots (1270 \pm 32 and $1267 \pm 34$ grams). In Karatetreated plots the weight of ears before shelling was recorded as $1717^{*} \pm 277$ grams, and after shelling total grain and cob weight was $1713 * \pm 276$ grams, showing significant variation with the check. In the case of the application of Endosulfan and Chlorpyrifos, weights of ears before shelling were found to be $1438 \pm 101$ and $1381 \pm 25 \mathrm{~g}$, while weights of grain + cobs after shelling were recorded as $1437 \pm 100$ and $1375 \pm 25$ g respectively, which indicated no significant variation when compared with those of check plots $(1270 \pm 32$ and

Table 6. Effect of treatments applied against Chilo partellus on crop yield; average number of yield per treatment recording before and after shelling.

\begin{tabular}{|c|c|c|c|c|c|}
\hline CT & NFP & WEBS & TWGCS & DWBAS & MC (\%) \\
\hline Cypermethrin & $6.7 \boldsymbol{a} \pm 0.58$ & $1963 \boldsymbol{c} \pm 126$ & $1960 \boldsymbol{c} \pm 126$ & $3.0 \pm 0.0$ & $15 \pm 0.86$ \\
\hline Endosulfan & $5.7 \pm 0.58$ & $1438 \pm 101$ & $1437 \pm 100$ & $1.3 \pm 1.5$ & $16 \pm 0.98$ \\
\hline Carbofuran & $7.3 \boldsymbol{b} \pm 0.58$ & $2111 \boldsymbol{c} \pm 113$ & $2107 \boldsymbol{c} \pm 114$ & $5.0 \pm 1.0$ & $15 \pm 0.91$ \\
\hline Karate & $6.7 \boldsymbol{a} \pm 0.58$ & $1717 \boldsymbol{a} \pm 277$ & $1713 \boldsymbol{a} \pm 276$ & $4.0 \pm 1.0$ & $15 \pm 0.20$ \\
\hline Chlorpyriphos & $5.3 \pm 0.58$ & $1381 \pm 25$ & $1375 \pm 25$ & $5.7 \pm 1.2$ & $15 \pm 0.90$ \\
\hline Check & $4.7 \pm 0.58$ & $1270 \pm 32$ & $1267 \pm 34$ & $3.0 \pm 1.7$ & $16 \pm 0.68$ \\
\hline
\end{tabular}

$\boldsymbol{a}\left({ }^{*}\right)$ significant, $\boldsymbol{b}(* *)$ higher significant, $\boldsymbol{c}(* * *)$ highest significant; While CT means chemical treatments, $\mathrm{T}_{1}$ Cypermethrin, $\mathrm{T}_{2}$ Endosulfan, $\mathrm{T}_{3}$ Carbofuran, $\mathrm{T}_{4}$ Karate, $\mathrm{T}_{5}$ Chlorpyriphos and $\mathrm{T}_{6}$ Check, NFP No of ears per five plants, WEBS Weight of ears before shelling, TWGCS Total weight of grain and cobs after shelling, DWBAS difference between weight before and MC after shelling, MC Moisture continent \%. 


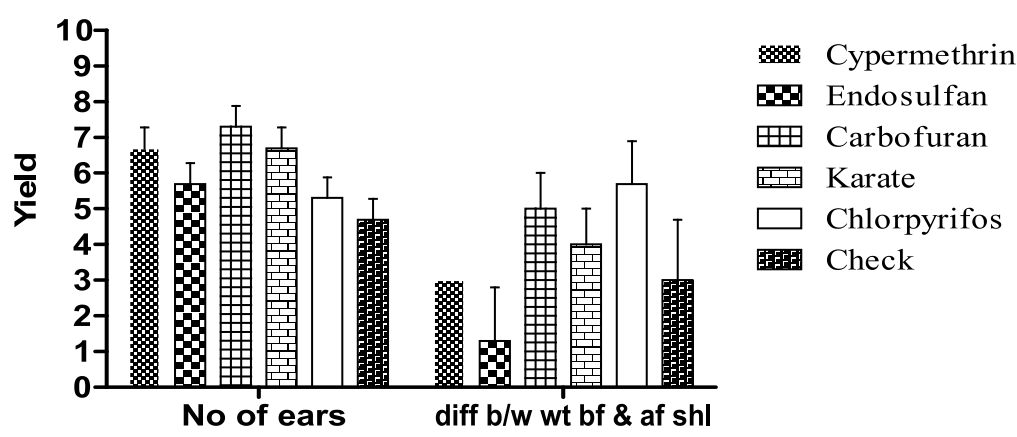

Fig. 6. Effect of treatments applied against Chilo partellus on crop yield (diff means different, b/w: between, wt: weight, bf: before, af: after, shl: shelling).

$1267 \pm 34 \mathrm{~g})$. It was finally determined from Table 5 that Carbofuran-treated plots produced the highest yield, followed by Cypermethrin, Karate, Endosulfan and Chlorpyrifos in ascending order. Moisture contents of the grains were determined with the help of a portable moisture tester - in the range of 15 to $16 \%$. The obtained results indicated that there was no considerable difference in moisture of the grains from all treated plots.

Results of the current study evidenced that $C$. partellus infestation remained significantly lower in all the granular and liquid treatments as compared to check (zero treatment). It was also found that the yield of maize was higher in the treated plots as compared to check, in which no chemical application was done. The most effective in this regard proved to be the granular form of insecticide, i.e., Carbofuran 3G, which not only controlled the $C$. partellus but also caused the highest yield of the maize grain. Similar results were obtained by many researchers in the past that used Carbofuran 3G against the maize stem borer [28]. These authors reported that the efficacy of Carbofuran was the highest in suppression of population of $C$. partellus as well as enhancement of grain yield.

In contrast, our findings cannot be exactly compared on the basis of the amount of efficacy, which might be due to variations induced by multiple factors, i.e., differences in methods of treatments, pesticide doses, stage of crop growth, status of the pest, and intensity of physical factors including temperature, relative humidity, degree and days, etc.

Best control was obtained by a single application of Carbofuran 3G in leaf whorl on 15-day-old crop [29]. Our results are in accordance with those reported by authors getting the highest efficacy of Carbofuran $3 \mathrm{G}$ in suppressing the $C$. partellus population when applied in plant whorl [30].

However, overall Carbofuran proved the best in controlling Chilo partellus larvae, plant damage, dead heart plants and increasing crop yield more than the other treatments in this trial. Moreover, the previous experiments proved that all the tested granular formulation efficiency controlled the target pest limited the formation of dead heart plant and reduced the damage caused by $C$. partellus. So, among these insecticides Carbofuran was the best one after Padon, followed by Diazinon $5 \mathrm{G}$ and Fipronil $0.3 \mathrm{G}$ and Disulfoton $5 \mathrm{G}$ in descending order as compared to check, respectively (Zahid khan unpublished data). In the previous work of Ahmed et al. [31], the reason for Carbofuran application that showed the least infestation in the plots treated with Carbofuran as compared to plots treated with Cypermethrin.

Results of the present studies show that the insecticide Cypermethrin proved the second most effective among the liquid-formulated treatments in controlling $C$. partellus in maize be comparable and in conformity with a number of previous workers [32].

In contrast, the performance of Chlorpyrifos $40 \mathrm{EC}$ was not so effective against the maize stem borer, which resulted in an enhanced amount of reduced plant damage. These results can be broadly corroborated with those obtained by Neupane et al. [33], who stated that Chorpyriphos (foliar application) was more effective than Cypermethrin. However, our results are not in close agreement with those reported by Bhat and Baba [34], who obtained efficient control of C. partellus by applying Chlorpyrifos, but such differences in efficacy may be due to many factors, e.g., environmental conditions, pest status, soil type, crop conditions, method of experimentation, etc.

The application of Endosulfan $35 \mathrm{EC}$ in the present experiment revealed that this insecticide was effective against plant injury, dead hearts and the larvae of the maize stem borer; similar opinions were also given by a number of previous researchers and support the results of our experimentation [31,34-35]. The application of the liquid insecticide Karate was not proved to be responsive treatment. Similar results were obtained by Singh et al. [36], who reported as a precise conclusion that liquid insecticides were less efficient than granular formulations.

In other words, a minimal increase in the concentration of recommended doses of insecticides can result in a significant modification in the lethal effect. In the present research, the recommended amount of Cypermethrin 10 EC $500 \mathrm{ml} / \mathrm{ha}$ applied was effective against $C$. partellus, while an excessive 
concentration of Cypermethrin 25 EC $1000 \mathrm{ml} /$ ha was evaluated by Kumar et al. [37] under field conditions against the Coccinella septumpunctata population. But Mamun and Ahmed [38] tested the granular form of Cypermethrin $10 \mathrm{EC} 100 \mathrm{~g} / \mathrm{ha}$ to kill the target tea pests. Similarly, the applied dose of Karate was $2.5 \mathrm{EC} 500 \mathrm{ml} / \mathrm{ha}$ in the current study to control maize pests, while the concentrated dose of lambda cyhalothrin 5 EC $500 \mathrm{ml} / \mathrm{ha}$ was used by Kumar et al. [37] against $C$. septumpunctata, which was also a more excessive amount than the lambda cyhalothrin 5 EC $300 \mathrm{ml} /$ ha tested by Dudhbale et al. [39] against Spodoptera litura infesting soybean to reduce loss. Furthermore, the Chlorpyrifos $40 \mathrm{EC}$ tested as standard dose on $500 \mathrm{ml} /$ ha was obviously more concentrated than the Chlorpyrifos 20 EC 10 lit/ha, 1000 lit/ha [38] and Chlorpyrifos 3.5 lit/ha, 2.5 lit/ha [40]. Dash and Mukherjee [41] applied Carbofuran 3G, $1 \mathrm{~kg} / \mathrm{ha}$ of which was comparative less than the Carbofuran $3 \mathrm{G} 20 \mathrm{~kg} / \mathrm{ha}$ used in present research, and recorded the most effective treatment in $C$. partellus mortality and increased crop yield. Like us, the same dose of Carbofuran $3 \mathrm{G}$ $30 \mathrm{~kg} /$ ha tested by Chakraborty [42] was found to be more effective for controlling yellow stem borer, Scirpophaga incertulas in the rice ecosystem. Endosulfan $35 \mathrm{EC}$ $500 \mathrm{ml} /$ ha experienced as the recommended dose in our research studies while these insecticides can be sprayed in different concentration doses for the expected control of pests such as Endosulfan (17.5\%, $35 \%, 50 \%$ ) EC or Cypermethrin $10 \mathrm{EC}$ aerial application on maize crop with modified doses of $100 \mathrm{ml} / \mathrm{ha}$, 125 to $175 \mathrm{ml} / \mathrm{ha}$ and 250 to $350 \mathrm{ml} / \mathrm{ha}$. The recommended doses of insecticides were found to be more effective than other doses against insect pests. While still now a numerous number of the farmers were not satisfied and feeling that the recommended insecticide doses largely applied could not provide the estimated control of pests [43]. The maximum field doses of insecticides caused the highest percentage mortality of larvae [44].

\section{Conclusions}

It can be concluded from the achieved results of the present experimentation that all the tested liquid and granular insecticides performed well in suppressing maize stem borer and reducing plant damage. However, Carbofuran proved to be the best in controlling C. partellus larvae, plant damage and dead heart plants. Similarly, crop yield in this treatment was computed more than in the other treatments. Cypermethrin ranked second in efficacy, giving more commendable results than other treatments. This chemical suppressed maize stem borer and reduced plant damage to a greater extent, resulting in higher levels of the grain yield. The next effective treatment was Karate, followed by Endosulfan and Chlorpyrifos in descending order.

\section{Acknowledgements}

This study was supported by the Director of Agriculture, Research station, Baffa, Mansehra. Similarly, the equal respect and credits are going to $\mathrm{Mr}$. Sana Ullah, Ph.D. student of the Zoology Department of Hazara University, Mansehra, who helped with statistical analyses. Mr. Waqar and Habib helped with data sampling in the field.

\section{Conflict of Interest}

The authors declare no conflict of interest.

\section{References}

1. ABID S.A., RAZA I.R., KHALIL A.L, KHAN M.N., ANWAR S.A., MASOOD M. A. Trend analysis and forecasting of maize area and production in Khyber Pakhtunkhwa, Pakistan. Eur. Acad. Res. 2 (4), 4653, 2014.

2. SHAKOOR U., RASHID M., SABOOR A., KHURSHID N., HUSNAIN Z., REHMAN A. Maize production response to climate change in Pakistan: A time series assessment. Sarhad J. Agric. 33 (2), 320, 2017.

3. TARIQ M., IQBAL H. Maize in Pakistan-An overview. Kasetsart J. (Nat. Sci.). 44 (5), 757, 2010.

4. KHAN I., HASSAN G., MALIK N., KHAN R., KHAN H., KHAN, S. Effect of Herbicides on Yield and Yield Components of Hybrid Maize (Zea mays). Planta Daninha. 34, (4), 729, 2016.

5. MUHAMMD N., ASHIQ M., GAFFAR A., SATTAR A., ARSHAD M. Comparative efficacy of new herbicides for weed control in maize (Zea mays L.). Pakistan Journal of Weed Science Research. 18, (2), 2012.

6. SHAKOOR U., RASHID M., SABOOR A., KHURSHID N., HUSNAIN Z., REHMAN A. Maize production response to climate change in Pakistan: A time series assessment. Sarhad J. Agric. 33 (2), 320, 2017.

7. GODFREY L.D., WRIGHT S.D., SUMMERS C.G., FRATE C.A. CORN. UC IPM online. Agriculture and Natural Resources, University of California., 1, 2014.

8. KARAVINA C., MANDUMBU R., MUKARO R. Evaluation of three-way maize (Zea mays 1) hybrids for yield and resistance to maize streak virus and turcicum leaf blight diseases. J. Anim. Plant Sci. 24 (1), 216, 2014.

9. SHAH B., KHAN I.A., KHAN A., DIN M.M.U., JUNAID K., ADNAN M., SHAH SRA., ZAMAN M., AHMAD N., AKBAR R., FAYAZ W., INAYAT-URRAHMAN. Correlation between proximate chemical composition and insect pests of maize cultivars in Peshawar. ¡J. Entomol. Zool. Stud. 4 (1), 312, 2016.

10. BIRADAR S.R., KOTIKAL Y.K., GOUD K.B., BALIKAI R.A., BIRADAR D.P. Seasonal incidence and management of insect pests in maize., 1, 100, 2010.

11. LA GRANGE R., SCHRÖDER M., GLINWOOD R., IGNELL R., KRÜGER K. Leafhopper interactions with host plants - a role for volatile cues? 40 Years of the IOBC-WPRS Working Group" Pheromones and Other Semiochemicals in Integrated Production. Bulletin OILB-SROP; 126, 22, 2017. 
12. QUISPE R., MAZÓN M., RODRÍGUEZ-BERRÍO A. Do Refuge Plants Favour Natural Pest Control in Maize Crops? Insects. 8 (3), 71, 2017.

13. AHAD I., BHAGAT R.M., AHMAD H., MONOBRULLAH M. Population dynamics of maize stem borer, Chilo partellus Swinhoe in upper Himalayas of Jammu region. Sher-e-Kashmir University of Agricultural Sciences and Technology, Jammu-180001, India. J. BioSci. 16, 137, 2008.

14. JINDAL J., HARI N. S. Resistance in maize to Chilo partellus swinhoe (Lepidoptera: Crambidae). J. Entomol. Res. 34, 0974, 2010.

15. TEFERA T., MUGO S., MWIMALI M., ANANI B., TENDE R., BEYENE Y., GICHUKI S., OIKEH S.O.,

NANG'AYO F., OKENO J., NJERU E. Resistance of Bt-maize (MON810) against the stem borers Busseola fusca (Fuller) and Chilo partellus (Swinhoe) and its yield performance in Kenya. Crop Prot. 89, 202, 2016.

16. CHOURADDI M., MALLAPUR C.P. Assessment of crop loss and economic injury level of maize stem borer, Chilo partellus (Swinhoe). J. Entomol. Zool. Stud. 5 (4), 1530, 2017.

17. KUMAR R., ALAM T., RAI A.K. Symptom based artificial screening of promising maize germplasm against Chilo partellus (Swinhoe). J. Entomol. Zool. Stud. 5 (5), 1019, 2017.

18. SHARMA P.N., GAUTAM P. Assessment of yield loss in maize due to attack by the maize borer, Chilo partellus (Swinhoe). Nepal J. Sci. Technol. 11, 25, 2010.

19. BHANDARI G., ACHHAMI B.B., NEUPANE S., SHARMA S.D. Differential resistance reaction of maize genotypes to maize stem borer (Chilo partellus Swinhoe) at Chitwan, Nepal. Journal of Maize Research and Development. 23, (1), 133, 2016.

20. KUMAR R., ALAM T. Bio-efficacy of some newer insecticides against maize stem borer, Chilo partellus (Swinhoe). J. Entomol. Zool. Stud. 5 (6), 1347, 2017.

21. KHAN M.I., FARID A., KHAN A.M., KHATTAK S.U., SATTAR A. Studies on maize stem borer, Chilo partellus in Peshawar valley. Insect Environ. 9, 45, 2007.

22. KHAN I.U., NAWAZ M., FAZAL S., KAMRAN S. Integrated pest management of maize stem borer, Chilo partellus (Swinhoe) in maize crop and its impact on yield. J. Entomol. Zool. Stud. 3 (5), 470, 2015.

23. ARUNKUMARA C.G., BHEEMANNA M., SHAILA H.M. Field evaluation of insecticides for management of spotted stem borer, Chilo partellus (Swinhoe) (Lepidoptera: Crambidae) on maize. J. Entomol. Zool. Stud. 5 (5), 1719, 2017.

24. IQBAL J., FAROOQ S.U., ALQARNI A.S., ALI H, ZESHAN A., ANSARI M. J. Management of maize stem borer (Chilo partellus) with insecticides of three formulations under field conditions. Indian J. Agr. Sci. 87 (12), 1720, 2017

25. MASHWANI A.M., ULLAH F., SATTAR S., AHMAND S., KHAN M.A. Efficacy of different insecticides against maize stem borer, Chilo partellus swinhoe (Lepidoptera: Pyralidae) at Peshawar and Swat valleys of Khyber Pakhutunkhwa, Pakistan. Sarhad J. Agric. 27 (3), 459, 2011.

26. VISHVENDRA D.V., KUMAR S., KUMAR R., VAIBHAV V. Screening of Maize Cultivars against Maize Stem Borer Chilo partellus (Swinhoe), under Natural Field Condition. Int. J. Curr. Microbiol. App. Sci. 6 (10), 1414, 2017.
27. SALEEM A.M., AHMED N., KHAN K. District profile Mansehra, Islamabad., Earthquake Reconstruction and Rehabilitation Authority; 1, 2007.

28. RAUF A., AYYAZ M., BAIG F., NAQQASH M.N., ARIF M.J. Response of Chilo partellus (Swinhoe) and entomophagous arthropods to some granular and new chemistry formulations in Zea mays L. J. Entomol. Zool. Stud. 5 (3), 1351, 2017.

29. SALEEM Z., IQBAL J., KHATTAK S.G., KHAN M., MUHAMMAD N., IQBAL Z., KHAN F.U., FAYYAZ H. Effect of different insecticides against maize stem borer infestation at barani agricultural research station, Kohat, KPK, Pakistanduring Kharif 2012. Int. J. Life Sci. Res. 2 (1), 23, 2014.

30. ZULFIQAR A.M., SABRI M.A., RAZA M.A., HAMZA A., HAYAT A., KHAN A. Effect of temperature and relative humidity on the population dynamics of some insect pests of maize. Deptt of Entom, University of Agriculture, Faisalabad-Pakistan. Pak. J. Life. Soc. Sci. 8, 16, 2010.

31. AHMED S.O., ANJUM S.H., NAEEM M., ASHRAF M.Y. Determination of efficacy of Cypermethrin, Regent and Carbofuran against Chilo partellus Swin and biochemical changes following their application in maize plants. Int. J. Agr. Biol. 5 (1), 30, 2003.

32. GUPTA S., HANDORE K., PANDEY I.P. Effect of insecticides against Chilo partellus (Swinhoe) damaging Zea mays (maize). Int. J. Parasitol. Res. 2 (2), 04, 2010.

33. NEUPANE S., BHANDARI G., SHARMA S.D., YADAV S., SUBEDI S. Management of stem borer (Chilo partellus Swinhoe) in maize using conventional pesticides in Chitwan, Nepal. Journal of Maize Research and Development. 2, (1), 13, 2016.

34. BHAT Z. H., BABA Z.A. Efficacy of different insecticides against maize stem borer, Chilo partellus (swinhoe) and maize Aphid, Phapalosiphum maids (Fitch) infesting maize. Pak. J. Entomol. 29 (2), 73, 2007.

35. RAGHUVANSHI V.S., RANA K.S. Effect of pesticides against Chilo partellus (Swinhoe) damaging stem of maize. Int. J. Life Sci. Pharm. Res. 1, 101, 2012.

36. SINGH B.U., RAO K.V., SHARMA H.C. Comparison of selection indices to identify sorghum genotypes resistant to the spotted stem borer Chilo partellus (Lepidoptera: Noctuidae). Int. J. Trop. Insect Sci. 31, 38, 2011.

37. KUMAR S., SINGH G., KUMAR S., SAIN Y. Evaluate the effect of novel insecticides on Coccinella septumpunctata population under field condition in black gram. Prog. Agric. 15 (2), 208, 2015.

38. MAMUN M.S.A., AHMED M. Integrated pest management in tea: prospects and future strategies in Bangladesh. The Journal of Plant Protection Sciences. 3, (2), 1, 2011.

39. DUDHBALE C., SURPAM A., KOTHIKAR R., KOCHE M. Bio-efficacy of chemical insecticides against Spodoptera litura infesting soybean. American Journal of Entomology. 1, (1), 16, 2017.

40. SINGH A.P.B., KUMAR A., SINGH D.V. Field evaluation of Beauveria bassiana and Metarhizium anisopliae against major insect pest on paddy (Oryza sativa L.). Progress Agric. 15 (1), 62, 2015.

41. DASH A.N., MUKHERJEE S.K. Insecticidal control of major insect pest of rice. Pest Management and Economic Zoology. 11, (2), 147, 2003.

42. CHAKRABORTY K. Assessment of the efficacy of some bio-rational pesticide formulations for the management of 
yellow stem borer, Scirpophaga incertulas Wlk. in paddy field. J. Biopest. 4 (1), 75, 2011.

43. PATIL S.R., LANDE G.K., AWASTHI N.S., BARKHADE

U.P. Effect of different doses of newer insecticides against sucking pests of okra. The Bioscan. 9 (4), 1597, 2014.
44. PELIZZA S.A., SCHALAMUK S., SIMÓN M.R., STENGLEIN S.A., PACHECO-MARINO S.G., SCORSETTI A.C. Compatibility of chemical insecticides and entomopathogenic fungi for control of soybean defoliating pest, Rachiplusia nu. Rev Argent. Microbiol. 50 (2), 189, 2018. 